\title{
The Semantic and Etymological Peculiarities of the Verbs of Blame
}

\author{
Tamara M. Timoshilova*, Elena N. Morozova, Elena V. Shemaeva, \\ Natalya B. Kudryavtseva and Julia V. Golubeva
}

Belgorod State University, 85 Pobeda Street. Belgorod, Postcode 308015, Russia

\begin{abstract}
The article deals with the semantic analysis of the verbs of blame (brawl, castigate, condemn, curse, damn, lecture, rate, rebuke, reprehend, reprimand, reproach, reprobate, reprove, row, strafe, swear, trounce) in the perspective of semantics, as well as etymology. In accordance with the dominant cross-disciplinary approach to the linguistic research, the semantics of the verbs under study is analyzed in correlation with the relevant extra-linguistic data. It reveals the necessity of using some data of cognitive linguistics together with etymological methods of semantic analysis. The complex of cognitive and etymological methods helps to determine the functioning of the verbs in different kinds of discourse, and to find the closest equivalent in the Russian language.
\end{abstract}

Keywords: Semantics, verbs of blame, semantic analysis, etymological analysis, social impact, moral and psychological harm, synchronic and diachronic approaches.

\section{INTRODUCTION}

Recent linguistic researches often deal with the living being as an active participant who has an individual and social experience, his own system of knowledge of the surrounding world and its reflection in his consciousness in the form of conceptual objective reality. Anthropocentric linguistics investigates the language in close correlation with the individual. That's why anthropocentrism is used as a methodological basis of recent linguistic researches. In other words, the given approach emphasizes the fact that language is a many-sided and many-facet phenomenon that can be reflected on the language level (Gumboldt 1984).

Language is one of the main attributes of a living being and reflects anthropocentric "traces" in its system. The recent linguistic researches in cognitive linguistics prove it. The Language "was created to measure a person and this scale can be seen in the organization of language in accordance with which the language should be studied" (Stepanov 2002).

Modern linguistics studies linguistic consciousness "where consciousness expresses itself outwardly verbal and is affected by the language" (Ushakova 2000; Watts2010). Its aim is "to find a way to the person through language". In order to reach this aim different strategies are used such as synchronic and diachronic aspects of language description: an investigation of phraseological units and parables, metaphors and cliché, the semantics of a word through its conceptual analysis, associative fields on which the

*Address correspondence to this author at the Belgorod State University, 85 Pobeda Street. Belgorod, Postcode 308015, Russia;

E-mail: kozina.n.vladimrov3@gmail.com average type of a native speaker of a particular culture is built.

\section{OBJECTIVES}

The article deals with the semantic analysis of the verbs of blame (brawl, castigate, condemn, curse, damn, lecture, rate, rebuke, reprehend, reprimand, reproach, reprobate, reprove, row, strafe, swear, trounce) in the perspective of semantics, as well as etymology.

\section{METHODOLOGY}

By the dominant cross-disciplinary approach to the linguistic research the semantics of the verbs under study is analyzed in correlation with the methods of cognitive and etymological analysis. The complex of conceptual and diachronic etymological methods allows tracing important mechanisms in the structure of lexical unit meanings. It reveals the necessity of using some data of cognitive linguistics together with etymological methods of semantic analysis. The complex of cognitive and etymological methods helps to determine the functioning of the verbs in different kinds of discourse, and to find the closest equivalent in the Russian language.

The most complete disclosure of the content of a word is only possible with the integration of objective and subjective characteristics of the described situation of speaking, considering the specific features of its perception, definite knowledge about it. The latter is possible for both analyzing the structures of knowledge behind a particular tag and detailed etymological analysis of verb meanings. 


\section{RESULTS AND DISCUSSION}

As it is mentioned above the object of the ongoing research is constituted by the semantic group of verbs denoting verbs of blame in the contemporary English language. This group includes lexemes to brawl, to castigate, to condemn, to curse, to damn, to lecture, to rate, to rebuke, to reprehend, to reprimand, to reproach, to the reprobate, to reprove, to row, to strafe, to swear, to trounce denoting different degrees of blame. All these verbs belong to the group of verbal influence. The typical semantic feature of them is to pronounce something expressing a different emotions and helping to create different emotional condition of the recipient of the conversation and force him to react. Verbal influence can have negative and positive sides. The verb "blame" has a negative connotation. Blame is a verbal activity in which the aim of a person standing higher on the social stair is to express negative evaluation for action or no action and see the reaction of the recipient (Kolosov 2002; Watts 2017).

The blame can be analysed as a representative showing the reality of affairs, and as an expressive showing dissatisfaction of the speaker with this position and direction, because the purpose of censure is not just to inform the addressee, but to induce him to confess guilt, promise to improve (Emelyianova 2004).

Verb lexemes with the meaning of blame are the part of the lexical layer with the meaning of "to spoil, to ruin" and linguistic means of explication of the concept DAMAGE (PORCHA).

Semantic and derivational structure of verbs reflects changes happening in the life of contemporary society. Words understudy with the semantic component "to spoil, to ruin" could not be better able to describe the state of modern society, which in the last decades of the $X X$ century and the beginning of the $X X I$ century is impossible to imagine without such concepts as "damage, destruction, harm", including verbal (moral) harm. The concept under study touches almost all spheres of human activity.

The origins of the formation of meanings "blame", "damage", "harm", "spoilage" have a close relationship with the concept of "violation" and go back, probably to the beginning of the creation of the world, or rather, for the first violation (the temptation of Eve by the Serpent). These concepts are interpreted through more global oppositions good/evil, covering/concealing intentions, deformation/distortion, disruption of the existing order of things, etc (Krasavskiy 2001; Muyambiri \& Chabaefe, 2018; Chahine, 2018).

The concept of damage is, in our opinion, a part of a more global category - the category of evil, thereby causing its consideration in close connection with this concept.

Von Wright notices that the noun "evil" is used to denote the cause of harm and the harm caused. The word "harm" is usually applied only to the result caused by evil (Wright 1963).

Verbs meaning "to spoil, to ruin", as well as verbs of "censure" inherent component of "change", pointing to a limit of the process. The limiting processes are those that due to their internal nature allow us to predict that at the time of their completion will come to a certain state (Holodovich 1979; Watts 2006). This state can be defined as the state in which the person (object) under the influence changes the emotional state into the negative or there is a rearrangement of the values.

In essence, the concept DAMAGE (PORCHA) is heterogeneous and multi-dimensional (the phenomenon of damage/corruption covers physical and objective, moral and mental damage). The verbs under study are lexemes-the representatives of the conceptual field of MORAL and MENTAL DAMAGE (PORCHA).

The group with the integral component "to scold" is presented by the central verb to swear, whose meaning indicates the emotional colour of spoken words, which have reached the higher limit of swearing, as it affected the God whom we customary treat with reverence, not with bad words. The verb "to strafe" is close to the verb "to swear" and indicates that this process can be continued long and can touch any sphere of human relations because there are no limits and no boundaries are preventing this negative process.

The verb "to brawl" - "to quarrel, brawl, scream" occupies an intermediate position between the first group and the second represented by the main verb "to curse" with the integral meaning "curse" which is considered the highest point in swearing, as they touch the area of black magic that can damage not only the object of the action but also the speaker himself (the subject of the action) because a bad word spoken in an evil hour has the property of a boomerang and returns to his master. Indeed, people directing the curse potentially, for scientists in the field of magic, start a 
negative program affecting them destructively over time. The same can be said about the verb "to damn". The action of the verbs understudy can be treated as a deliberate action aimed at the object with a specific purpose, the result of which is the damage caused to the object. This method of impact will relate to neurolinguistic influence, which may be represented by verbal/non-verbal influence, hypnosis, persuasion, etc.

The group of verbs with an integral meaning of "a rebuke, reprimand" is presented by the central verbs to rebuke, to reprehend, to reprimand, to reprove, to row. The meaning of these verbs shows the gradual strengthening of the discontent on the part of the subject. The verb to lecture shows the desire of the speaker to correct the situation using a simple admonitory talk that can be understood by the person or can be ignored. The intensification of the feeling of discontent can be noticed in the meanings of verbs to condemn, to reprobate. The subject of the action (the speaker) uses a stronger form of reprimand - a reproach to change the situation and try to put a person in his place, hoping that the conviction is an effective way of resolving the conflict. Gradually reproach turns into abuse which indicates the inability to control emotions, to handle the situation, this is the functional significance of lexemes to castigate - "to scold, severely criticize", to rate - "to scold", to reproach - "to rebuke, to scold", to trounce - "sternly scold".

The presence of the negative evaluation in the definitions of the markers allows us to talk about the violation of the norms or standards. According to the data of authoritative lexicographical sources, we conclude that lexemes have a common integral sign that is a negative impact on someone or something, especially negative impact on somebody's reputation.

The analyzed verbs possess a conceptual dimension of "infliction of emotional damages", "negative impact on reputation", "to upset relations". This achieved state (damaged or spoiled) put these verbs of blame in one group with the verbs of damage (porcha). Therefore, we indicate of action and state that are achieved by the action. These verbs are also characterized by their polysemy and transitivity/intransitivity depending on constructions, that is why there are some difficulties in the study of the semantics of the given verbs.

The meaning of these lexemes can be interpreted as "to cause pain, moral damage".
According to G. I. Kustova there are different results and different possibilities of interpretation in any action, also other schemes can be extracted under other conditions from this action (Kustova 2004).

\section{Etymological Aspect of the Verbs of Blame}

Semantic features of the analyzed category enable us to examine the verbs of blame that have the following etymological characteristics:

to brawl - "squabble, noisy quarrel" (COD). It is dated to XIV century. In late ME. it had such forms as brawle, braule, bralle. Nowadays its etymology is not clear. One of the versions shows the connection of the verb with the Germ. root *brōl-. It can be found in HG. brallen "shout loudly", MHG. brellen "roar, shout", Schwab Brall "wild, shrill cry" and MHG. pral "noise, sound".

Relaxed ablaut (in comparison with the traditional transition $a-\bar{o}$ ) is found in MDu. MLG. brullen "roar". This lexical group is based on onomatopoeia. But the origin is unknown. There are some attempts to correlate the ties with MDu. bullen "to make a noise, rage, angry", OHG. bullen, büllen "to howl, bark, roar". The emphatic $r$ is seen in these words. They relate to G. bellen that refers to the onomatopoeic IE. root *bhel"sound, speak, roar, bark".

to castigate - "chastise, punish with blows or words" (COD). The verb appeared in English in the XVII century. It is a borrowing from L. castīgāre (ODEE) "to rebuke, to scold" (LRD, p. 125), the meaning of the verb almost has no transformations (English-Russian Dictionary 1978).

to condemn - "censure, blame; give judgement against" (COD). It is dated XIII century. Through OF. condem $(p)$ ner it has been referred to $L$. condem(p)nāre (ODEE) "to condemn, to blame" (LRD).

to curse - "utter curses; blaspheme" (COD). The cognate noun was transposed into the category of verbs and fixed in OE. In the form cursian the verb appeared in late OE. The origin of the verb is unknown. It has been referred to Olr. cūrsagim "I censure, chastise" (ODEE).

to damn - "condemn, censure; cause the damnation of; curse" (COD). It is dated XIII century with the meaning "to condemn"; in XIV century it got the meaning "to doom to eternal perdition" in XVI century the meaning "to be accursed" is added to the semantics of the verb. 
Through OF. damner the verb has been referred to $L$. damnāre (ODEE) "to condemn, to blame" (LRD).

to lecture - "deliver (on the subject); instruct or entertain (class etc.) by lecture; admonish, reprimand" (COD). It was fixed in English in XVI century. According to the lexicographic sources, it belonged to Roman lexemes to IE. *leg-, ${ }^{*}$ log- (ODEE). The etymological analysis of German cognates allows finding IE. *legh"to lay down, to lie" (EWD). This initial meaning was metaphorically transformed into "to have the facts as presented, to read a lecture" with the further modification "admonitive talk, to tell off".

to rate - "scold angrily; storm at" (COD). It is dated XIV century. Through an outdated form a rate, the rate is referred to OF. (a) reter which in turn comes from the Latin verb reputāre (ODEE) "to calculate, to think about" (LRD). The Latin verb with the prefix goes back to the root putāre -"to fix the amount of/settle scores/abacuses, to measure/weigh" (LRD). It is the initial meaning of "to fix the amount of/settle scores" that played a dominant role in the development of the semantics of the English verb "to scold, to rate".

to rebuke - "reprove, reprimand, censure authoritatively" (COD). It was fixed in English in the XIV century. Lexicographic sources point to the relative lexeme in OF. rebuchier which is formed with the help of the prefix re "back from the starting point" and the verb buschier "to beat, to strike, to cut down wood" (ODEE). The semantic development of the verb had the metaphorical basis of the transformation of "repel" $\rightarrow$ "to reproach, to damage the reputation of reprimand".

to reprehend - "rebuke, blame, find fault with"(COD). It was fixed in English in XIV century. It is borrowed from L. re-prehendere (ODEE) "to condemn, to blame" (LRD).

to reprimand - "official(ly) rebuke (for fault)" (COD). In XVII century the verb was borrowed from French réprimander (ODEE). In the stem of the French borrowing, we can find L. verb re-primere "to push, to suppress" (LRD).

to reproach - "upbraid, scold; rebuke (offence)" (COD). It is fixed in English in XV century and is referred to OF. reprochier (contemp. reprocher) (ODEE). In the adapted borrowing we can find Latin prefix re - with the meaning of opposite direction from the starting point and the root prope "near, close" (LRD) (ODEE). The meaning of the verb develops on the metaphorical reinterpretation "to deprive of the starting position" $\rightarrow$ "to damage the reputation with the help of rebuke."

to reprobate - "express or feel disapproval of, censure" (COD). It is dated XVI century. It is an adapted borrowing from Latin reprobāre (ODEE) "not approve, condemn" (LRD), the meaning of which hasn't suffered significant modification.

to reprove - "rebuke, chide" (COD). It was fixed in English in XVI century. It is described as borrowing from OF. reprover (ODEE). The Latin verb reprobāre "not endorse, condemn" (LRD) is the basis of the etimon.

to row - "reprimand, rate" (COD). It is dated XVIII century (according to COD). The origin is unknown. Through the German lexeme rauh, OE. rūh, Eng. rough "hoarse, rough" it can be theoretically referred to IE. root "reuk-, "rūk- "to shout, to call", which is gutturally extension IE. *reu-, "reuə- "to break, dig, rake" (EWD).

to strafe - "reprimand or abuse" (COD). It belongs to $X X$ century (ODEE). It is believed that it originated in one of the Germanic languages and spread in the German area. In German the cognate verb is recorded in about 1200 . It is believed that its basis there is, a labial extension of the IE. root *(s)ter(ə)- "frozen, petrified" that has transferred in the form of IE. "strep(EWD). Semantic transformation "immobility" $\rightarrow$ "limited mobility, punishment" is possible.

to swear - "state something on oath, take oath, promise on oath, say emphatically that; use profane oaths to express anger" (COD). It is fixed in English in $X V$ century (ODEE). However, through cross-lingual parallels (OHG. swerren (VIII century), Sw. svar, OScand. svara and others) it can belong to the most ancient layer of the German vocabulary. In the ground of the verb, apparently, lies IE. root "suer- "say". Nevertheless, the question remains open, if the IE. root "suer- "growling, roaring" is the onomatopoeic root which is found with old Indian svárati "sound, hear (sound)", which later was transformed into "say". Therefore, the tie with the modern semantics of verbs from IE. root *uer- "speak solemnly, speak" looks more preferable. It is believed that this root is used with the initial mobile consonant s- (EWD).

to trounce - "beat severely, castigate" (COD). It was fixed in English in XVI century. The origin is unknown though lexicographic sources point to the relative lexeme in OF. troncer "to break, crumble" (ODEE) The possible development of both lexemes is their 
relationship with L. trānsīre "to discuss, to touch (in speech)" (LRD). This meaning could get in English negative connotation.

The given investigation shows that all the verbs of this lexical group do not belong to the group of archaic words as it was formed in XIV (4) and XVI (4) centuries.

They have the Romanesque and IE. origin. It can be explained by the development of language contacts and first of all by the adaptation of Romanesque borrowings but it doesn't change the lexical meaning of these verbs. The quantitative decline of augmentation was fixed in XVIII (1) and XX (1) centuries. It proves that this category is generally formed and can be enlarged due to the metaphorical shades of the lexical units.

\section{CONCLUSION}

Conceptual and etymological analysis of verbs of speech allowed to fulfill the investigation in the diachronic aspect and enrich the data of synchronic and conceptual analysis as etymology combines methods of analysis from Phonetics, Word Formation, Morphology, Lexicology, Semantics and others.

In other words, semantic etymological analysis allows the give the full comprehension of the phenomenon DAMAGE (PORCHA) as the phenomenon of the objective world, knowledge and people's experience which correlate with it and to find out the correlation between the meaning and its content status.

\section{RECOMMENDATIONS}

It is suggested that this study be considered in order to consider more and better the various dimensions of this verb and other verbs with both roots and meanings, so that the subject can be fully studied in different aspects of linguistics and cultural studies.

\section{REFERENCES}

Chahine, I. C. (2018). Exposing the Conscious Self: Lived Problem Solving Experience in a Socio-Cultural Context. International Electronic Journal of Mathematics Education, 13(3), 221-231. https://doi.org/10.12973/iejme/3880

Emelyianova, N.A. (2004). Conversational genre "claim" in different types of discourse in English: Dissertation of candidate of Philological Sciences. - Krasnodar, 181 p. (In Russian)

English-Russian Dictionary (1978). / edited by V.K. Muller. Moscow: Russian Language Publishers, 888 p. (ERD)
Etymologisches Wörterbuch des Deutschen 1989 / Leit. W. Pfeifer. Berlin: Akademie-Verlag.1-3: 1662 S. (EWD)

Gumboldt, V. (1984). Selected works in the study of language. Moscow: Progress, 400 p. (In Russian)

Holodovich, A.A. (1979). Problems of grammatical theory. Leningrad: Nauka, 304 p. (In Russian)

Kolosov, S.A. (2002). Concept as a subject of research in Linguistics. Language subsystems: stability and dynamics: collection of research papers. Tver, 28-33. (In Russian)

Krasavskiy, N.A. (2001). Emotional concepts in German and Russian cultures of language: Monography. Volgograd: Peremena, 495 p. (In Russian)

Kustova, G.I. (2004). Types of indirect meaning and mechanisms of extension. Moscow, 472 p. (In Russian)

Latin-Russian dictionary 1952 / edited by A.M. Malinin. Moscow, 763 p. (LRD) (In Russian)

Muyambiri, B., \& Chabaefe, N. N. (2018). The Finance-Growth Nexus in Botswana: A Multivariate Causal Linkage. Dutch Journal of Finance and Management, 2(2), 03. https://doi.org/10.20897/djfm/2634

Schwitter, R. (2017). Letters, Writing Conventions, and Reading Practices in the Late Roman World. Analysing Literary Reception in Late Antiquity and Beyond. Linguarum Varietas, 6, 61-77.

Shaw, B.D. (1990). Bandit Highlands and Lowland Peace: The Mountains of Isauria-Cilicia. Journal of the Economic and Social History of the Orient, 33, 155-300. https://doi.org/10.2307/3632208

Society and culture in late antique Gaul: revisiting the sources / R.W. Mathisen, D. Shanzer (eds). 2001. Ashgate, 328 p.

Stein, E. (1959). Histoire du Bas-Empire. Paris: Desclée de Brouwer, 566 p. (In French).

Stepanov, Y.S. (2002). Emil Benvenist and linguistics on its way to transformation. An introductory article to the book $E$. Benvenist "General Linguistics". Moscow: Editorial URSS, 444 p. (In Russian)

Straub, J. (1943). Die Wirkung der Niederlagebei Adrianopel auf die Diskussion uber das Germanenproblem in der spatromischen Literatur. Philologus, 296 p. (In German). https://doi.org/10.1524/phil.1943.95.14.265

The Concise Oxford Dictionary of Current English 1956 / edited by H.W. Fowler and F.G. Fowler. Oxford University Press, 1536 p. (COD)

The Oxford Dictionary of English Etymology 1966 / edited by C.T. Onions. Oxford.1026 p. (ODEE)

Trequattrini, R., Lombardi, R., Lardo, A., Cuozzo, B. (2018). The impact of entrepreneurial universities on regional growth: a local intellectual capital perspective. Journal of the Knowledge Economy, 9(1), 199-211. https://doi.org/10.1007/s13132-015-0334-8

Ushakova, T.N. (2000). Linguistic consciousness and rules of its study. Linguistic consciousness and images of the world. Moscow: URSS. 12-27. (In Russian)

Van Dam, R. (1985). Leadership and Community in Late Antique Gaul. Berkeley, L., Los Angeles, 350 p.

Vedeshkin, M.A. (2019). Jedvard Uotts i sovremennye issledovanija pozdneantichnogo obrazovanija. Hypothekai: zhurnal po istorii antichnoj pedagogicheskoj kul'tury, 3. Obrazovanie v pozdnejAntichnosti. M.: Akvilon: 301-305. (In Russian). https://doi.org/10.32880/2587-7127-2018-3-3-301-305

Watts, E.J. (2006). City and School in Late Antique Athens and Alexandria. The Transformation of the Classical Heritage 41. Berkeley - Los Angeles, $302 \mathrm{p}$. https://doi.org/10.1525/california/9780520244214.001.0001 
Watts, E.J. (2010). Riot in Alexandria: Tradition and Group Dynamics in Late Antique Pagan and Christian Communities. Berkeley: University of California Press, 290 p. https://doi.org/10.1525/california/9780520262072.001.0001
Watts, E.J. (2017). Hypatia: The Life and Legend of an Ancient Philosopher. New York: Oxford University Press, 224 p.

Wright, G.H. (1963). The varieties of goodness. London: Routledge \& K. Paul; New York: Humanities Press, 222 p.

Received on 28-08-2020

DOI: https://doi.org/10.6000/1929-4409.2020.09.108

(C) 2020 Timoshilova et al.; Licensee Lifescience Global.

This is an open access article licensed under the terms of the Creative Commons Attribution Non-Commercial License (http://creativecommons.org/licenses/by-nc/3.0/) which permits unrestricted, non-commercial use, distribution and reproduction in any medium, provided the work is properly cited. 